\title{
Farmācijas doktors profesors Jānis Maizīte - viens no farmācijas muzeja veidotājiem
}

\author{
Inta Vegnere
}

Pagājušajā gadā vienam no pirmās Latvijas brīvvalsts laika ievērojamākajiem farmaceitiem profesoram Jānim Maizìtem apritēja 125 gadi. Profesors allaž atradies tālaika farmaceitu sabiedriskās dzìves centrā, līdzcilvēki viṇu dēvējuši par Latvijas farmaceitu dvēseli.

Jānis Maizīte dzimis 1883. gada 10. maijā Liepas pagasta Leču mājās kalēja ǵimenē. Izglìtîbu ieguvis Liepas pagastskolā, pēc tam mācījies privātā vidusskolā Valmierā. 1898. gadā kā eksterns nokārtojis eksāmenu Rīgas Nikolaja ǵimnāzijā.

Vēlēdamies iepazìties ar farmāciju, Jānis Maizìte no 1898. līdz 1901. gadam strādājis par aptiekāra mācekli Vjazmas aptiekā. 1901. gadā Tērbatas Universitātē kā eksterns nokārtojis aptiekāra palīga eksāmenu. Pēc tam līdz 1904. gadam strādājis dažādās Krievijas aptiekās (Strahovā, Astrahaņā). 1904. gadā J. Maizīte iestājies Tērbatas Universitātes Medicīnas fakultātes Farmācijas nodaḷā, kuru beidzis 1908. gadā, iegūstot provizora specialitāti. Pēc tam turpat iecelts par jaunāko laborantu (asistentu), bet 1914. gadā - par vecāko asistentu. 1909. gadā. J. Maizīte nokārtojis mutiskus un rakstiskus eksāmenus farmācijas maǵistra grāda iegūšanai un profesora I. Kondakova vadībā uzsācis darbu pie maǵistra disertācijas "Par pinēna halogēnhidrātiem un to pārvēršanos ciklēna un santēna tipu og̣̣ūdeņražos". Bet sākoties I Pasaules karam, Jāni Maizìti iesauca aktīvajā karadienestā par rezerves farmaceitu, tāpēc viņš šo darbu nepaguva aizstāvēt. Tikai 1924. gadā darbu par maǵistra disertācijas tēmu viņš publicēja kopā ar savu skolotāju.

Līdzās terpēniem J. Maizìtes zinātniskās intereses saistījās arī ar ēteriskajām elı̄ām. 1911. gadā viṇa konkursa darbs par ēterisko ellıu ražošanu Krievijā apbalvots ar Suvorova zelta medaḷu. 1912. gadā J. Maizīti komandēja uz Krimu un Kaukāzu, lai viņš iepazìtos ar ārstniecỉbas augu kultivēšanu un ēterisko ellıu ražošanu. J. Maizìte bija viens no pirmajiem, kas pētīja Sibīrijas baltegles (Abies sibirica) ellıu, kuru vēlāk sāka izmantot kampara ražošanai. 1913. gadā par konkursdarbu "Skujkoku 


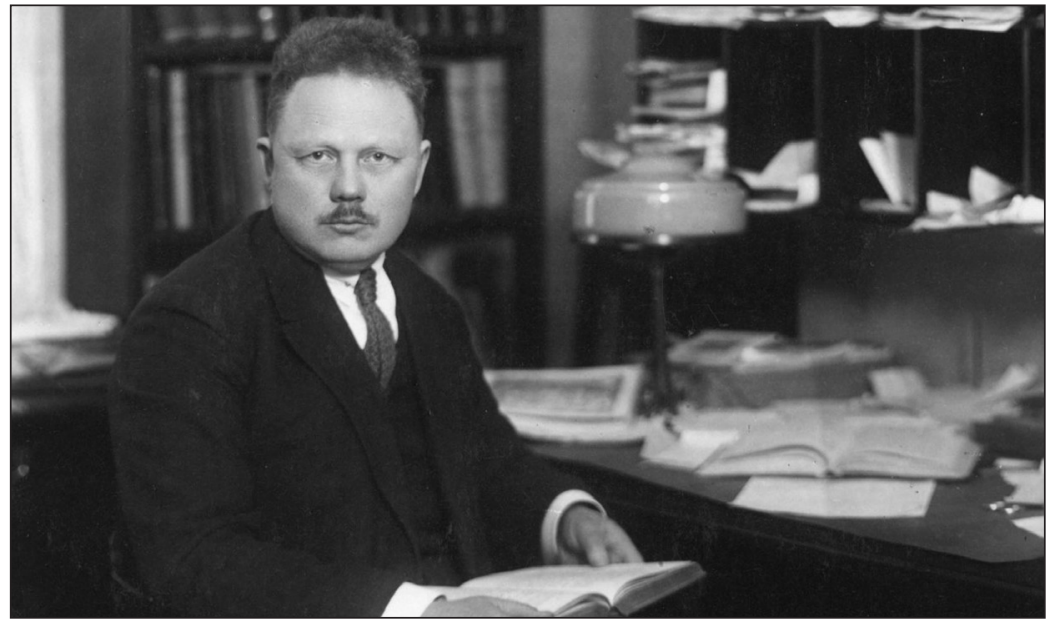

atsveķošana Krievijā un tajā iegūtie atsveķošanas blakusprodukti" J. Maizīti apbalvoja ar Universitātes Kreslavska zelta medaļu un komandēja uz ārzemēm (Mārburgas un Vīnes universitātēm). Pirmā Pasaules kara laikā Maizìti iecēla par 307. lauku hospitāḷa aptiekas pārvaldnieku, vēlāk par 6. lauku aptiekas nodaḷas pārzini, bet 1916. gadā - par farmaceitu darbvedi armijas štāba sanitārajā nodaḷā.

Pēc demobilizācijas J. Maizīte aizbrauca uz Voroṇežu, kur dạ̦ēji bija evakuēta Tērbatas Universitāte. 1918. gada rudenī viṇu šeit ievēlēja par Farmācijas katedras docentu. Jaunatvērtajā Voroṇežas farmācijas skolā viņš docēja farmācijas ḳīmiju un kvantitatīvo analīzi, lasìja lekcijas arī vairākos speciāli organizētos kursos. Vienlaikus viņš bija Voroṇežas farmaceitiskās fabrikas k̦īmijas nodal̦as vadìtājs.

Pēc atgriešanās Latvijā 1921. gadā J. Maizìti ievēlēja par Latvijas Universitātes Ķīmijas fakultātes docentu, bet jau 1922. gadā viņš kḷuva par vecāko docentu farmācijas ḳīmijā.

Profesors Maizīte aktīvi darbojās sabiedriskajā dzīvē. Viņš piedalījās pirmā Latvijas farmācijas likuma izstrādāšanā, pārstāvēja Latvijas farmāciju vairākos starptautiskos kongresos un konferencēs, arī Baltijas valstu aptiekāru konferencēs 1937. gadā Tallinā un 1939. gadā Rīgā. Profesors J. Maizīte bijis Latvijas Farmaceitu biedrības pārstāvis Starptautiskajā farmaceitu federācijā un piedalījies šîs federācijas biḷetena izstrādē, viņš darbojies arī Eiropas ārstniecỉbas augu organizācijā un piedalījies starptautiskā drogu manuāla izveidošanā. No 1924. līdz 1926. gadam, no 1928. līdz 1931. gadam un no 1937. līdz 1939. gadam viņš bija LU Ķīmijas fakultātes sekretārs.

1936. gadā J. Maizìtem piešķīra Krišjāṇa Barona prēmiju par Latvijas skuju ellı pētījumu. İpašu uzmanību J. Maizīte pievērsa vietējo dabas produktu pētniecībai, skaidrojot to ḳīmisko sastāvu un îpašỉbas, izstrādājot jaunus paṇēmienus 
produktu labvērtības pārbaudei, meklēja iespējas izmantot vietējos produktus importēto vietā. Daudzus gadus viņš nodarbojās ar Latvijas paparžu detalizētu izpēti. 1937. gada 10. martā J. Maizìte aizstāvēja doktora disertāciju "Pētījumi par Latvijas paparžu ekstraktiem" un ieguva farmācijas doktora grādu; tajā pašā gadā viņu ievēlēja par profesoru. Maizìte daudz pētījis ne vien ārstniecības augus, bet arī farmācijas ḳimijas tehnologíjas jautājumus.

J. Maizìte bija Latvijas Farmakopejas (1940) izdošanas iniciators un galvenais redaktors, viņš sagatavoja šim izdevumam 157 rakstus. Sarakstijis arī pirmo farmācijas mācību grāmatu latviešu valodā "Ievads praktiskā farmācijā" (1946), kurā īpašu uzmanību veltīja uzlējumu, izvilkumu, novārījumu pagatavošanai, ārstniecības augu kvalitātes jautājumiem un pareizai augu ievākšanai, kā arī medicīnas preparātu nomenklatūrai. İpaši Jānis Maizìte interesējās par farmācijas un aptieku vēsturi. Sākot ar 1925. gadu viņš lasa LU Ķīmijas fakultātes studentiem farmācijas vēsturi. 1934. gadā piedalijāàs pirmajā Starptautiskajā farmācijas vēstures kongresā Bāzelē. 1939. gadā Latvijas Farmaceitu Žurnālā J. Maizìte rakstīja par eksponātu vākšanu jaunajam Farmācijas vēstures muzejam: "Šai muzejā būtu jāsatek visam, kas attiecas uz mūsu pagātni, tradīcijām, zinātni, kultūru un gadu simteṇu gaitām. Tur būtu jāsakopo viss tas, kas palicis no atsevišku aptiekas telpu iekārtas trauki, darbarīki, piestas, svari, atsvari, agrāko laiku zāḷu līdzekḷi un, zināms, arī grāmatas, receptes utt. L,oti vēlams būtu arī agrāko gadu aptieku mēbeles, it īpaši plaukti un galdi, kā arī aptieku attēli un biogrāfiski un bibliogrāfiski dati par tiem farmaceitiem, kas pazīstami zinātnē, sabiedriskā laukā, literatūrā un mākslā, it sevišḳi par tiem, kas nodarbojušies ar farmācijas pagātnes pētī̌̌anu. Liela vērtība, saprotams, tiks pievērsta arī tautas dziedniecības līdzekḷiem. Lai šāds Farmācijas muzejs atstātu pienācīgu iespaidu uz mums pašiem, farmaceitiem, un citiem muzeja apmeklētājiem, nepieciešama visu Latvijas farmaceitu un pa visām lietām aptiekāru sadarbība, un tamdēl Latvijas Farmaceitu biedrības aptiekāru sekcijas vadība nolēma lūgt visus aptiekārus un pārējos kolēgus paziṇot par vecu laiku lietām, kuras viṇi varētu nodot muzeja rīcībā, vai arī tos tieši piesūtìt muzejam, kas atrodas Rīgā, Baznīcas ielā 5."

Šo ideju Jānim Maizītem izdevās īstenot 1938. gadā, kad viṇš nodibināja LU Ķīmijas fakultātē Farmācijas vēstures muzeju un kḷuva par tā vadītāju. Muzeja pamatu veidoja Dāvja Blūmentāla kolekcija, kuru viņš testamentā bija novēlējis Latvijas Universitātes Ķīmijas fakultātes Farmācijas nodaḷai; Rīgas Farmaceitu biedrības un Kurzemes Farmaceitu biedrības arhīvs un Jāṇa Maizìtes personiskais vākums. Muzejs atradās profesora Jāṇa Maizìtes vadītās Farmācijas ḳimijas katedras telpās Rīgā, Baznīcas ielā 5. Farmācijas vēstures muzejam bija gan savs zīmogs, gan veidlapa. J. Maizìte un viṇa līdzstrādnieki darbu veica sabiedriskā kārtā.

Pēc profesora Jāṇa Maizītes nāves (1950. gada 14. februārī; apbedīts 2. Meža kapos) viņa izveidotais muzejs ar LVU rektora pavēli 1950. gada 8. martā tika nodots Medicinas fakultātes komisijai ar profesoru Paulu Stradiṇu priekšgalā. Tā- 
dējādi Jāņa Maizītes vākums saplūda kopā ar Paula Stradiṇa kolekciju. 1957. gadā izveidojās Medicīnas vēstures muzejs, kas pašreiz ir viens no lielākajiem šāda veida muzejiem pasaulē. Tā kā farmācijas vēsturei veltìtais muzeja kolekcijas apjoms bija ḷoti liels, tad radās iecere nodalīt farmācijas kolekciju un izveidot patstāvīgu aptieku muzeju. 1985. gadā tika pieņemts lēmums izveidot Farmācijas muzeju kā Paula Stradiña Medicīnas vēstures muzeja filiāli. Muzeju iekārtoja divās dzīvojamās èkās Vecrīgā, Riharda Vāgnera ielā 13 un 15. Šìs èkas ir 18. gs. arhitektūras piemineklis, kuras pēc īpaša projekta restaurēja Polijas speciālisti.

Pateicoties Jānim Maizìtem, Farmācijas muzeja rīcībā ir daudz vērtīgu eksponātu. Farmācijas muzejs apmeklētājiem atvērts 1988. gada pavasarī. Šim notikumam par godu 2008. gada aprīī Farmācijas muzejs svinēja savu 20 gadu jubileju, kurā atcerējās arī profesoru Jāni Maizīti.

\section{Vēres}

1. Dr. pharm. J. Maizìte - profesors. Latvijas Farmaceitu Žurnāls, Nr. 6, 1937, 237.-239. lpp.

2. Vecākais docents J. Maizīte - farmācijas doktors. Latvijas Farmaceitu Žurnāls, Nr. 3, 1937, 131.-132. lpp.

3. Vīksna A. Vecās aptiekas. Rīga: Zinātne, 1993. 160 lpp.

4. Vegnere I. No idejas līdz muzejam.//Acta Medico-Historica Rigensia. Vol. 8 (27). Rìga: 2007, 272.-275. lpp.

5. Jaunsila V., Šīmanska M., Stradiņš J. Jānis Maizìte un viņa ieguldijums Latvijas farmācijas attīstībā.//No Grindeḷa lìdz mūsdienām. Rīga: Nordik, 1996, 108.117. lpp.

6. Uzaicinājums Farmācijas vēstures muzeja lietā. Latvijas Farmaceitu Žurnāls, Nr. 1, 1939, 1.-32. lpp.

7. Latvijas Universitāte divdesmit gados: 1919-1939. 2. dal̦a. Rīga: LU, 1939, 173.-176. lpp.

\section{Doctor of pharmacy and Professor Jānis Maizīte - one of the founders of Museum for Pharmacy (Summary)}

\section{By Inta Vegnere}

In 2007 J. Maizite turned 125. The professor had worked as a reader in the University of Tartu, later in University of Latvia Chemistry department. He also was the initiator and editor of the first Latvian pharmacopoeia (1940) and the author of the first chemistry study book in Latvian. J. Maizite also had a great deal 


\section{Vegnere}

of interest in the history of pharmacy and pharmacies. He donated his collection to the University of Latvia, Chemistry department. After his death the collection was merged with the Pauls Stradinšs Museum for History of medicine. Since 1985 the Museum for Pharmacy is divided from it as a separate affiliate.

Inta Vegnere

farmacija@mvm.lv

Farmācijas muzejs 